\title{
ÂMBITO DE VALIDADE DA LEI DE PROCESSO ADMINISTRATIVO (LEI n 9.784/99) - PARA ALÉM DA ADMINISTRAÇÃO FEDERAL
}

\author{
UMA PROPOSTA DE INTERPRETAÇÃO CONFORME \\ A CONSTITUIÇÃO DE SEL' ARTIGO I'
}

BERNARDO STROBEL GUIMARÃES ${ }^{\prime}$

\begin{abstract}
1. Introdução: 2. Comentários ao caput: Âmbito de incidência da lei de processo administrativo - para além da Administração Federal: 2.2. Distinção entre processo e procedimento como pressuposto necessário para a fixação da incidência da LPAF e suas conting sências, 2.3. Fixação do alcance da Lei e interpretaçio possível da reserva Federativa do seu art. $1^{\circ}$, caput; 3. Comentários ao $\$ 1^{\circ}$ : O exercício da função administrativa como critério de fixaçăos da incidência da Lei $n^{\circ}$ 9.784/99; 4. Comentários ao $\$ 2^{\circ}$ : Impossibilidade de se determinar a incidencia da LPAF exclusivamente pelo critério orgânico ou subjetivo; 5. Conclusões pontuais.
\end{abstract}

\section{1 - Introdução}

Nada obstante a lei de processo administrativo nào figurar propriamente entre as novidades do direito administrativo brasileiro, muito ainda há de se trabalhar com ela para que se fixe seu real alcance. firmando-se, de ve $\angle$ por todas, als reais possibilidades de seu manejo ${ }^{2}$. Muito do instrumental contido na Lei ${ }^{\circ} 9.784 / 99$ (LPAF)

1 Mestrando en Direito Administrativo na Ĺniversidide de Sío Paulo - USP. especialista em Direito Administrativo e Direito Tributário.

2 Acerca da atualidade e possibilidades em aberto do tema. elogüentes as palavras de SUNDFELD. Carlos Ari: "O direito administrativo brasileiro sofreu. em 1949. am impato cujos efeitos devem se fazer sentir nos próximos anos, podendo-se antèer sua significatia transformação. A razão é o surgimento de dhas leis gerais sobre processo ton procedimento) administrative "(As Leis do Processo Administrativo - Lei Federall 9.784/99 e Lei Patulista 10.177/98. Processos e procedimento administrativo no Brasil, São Paulo: Malheiros, 2000, p. 17). 
ainda carece de ser estudado com os rigores que o tema exige e. portanto. aplicado de maneira corriqueira.

Aliás. o momento para repensar a Lei de Processo Administrativo não poderia ser mais propício, haja vista as próprias alterações que se fazem sentir no bojo do direito administrativo. Um dos pontos onde manifestamente a mudança manifesta-se é na necessidade, cada vez maior, de justificar-se o exercicio da função administrativa. Este influxo, mais do que impor a necessidade de se repensar o alcance da "motivação" dos atos estatais, predica si necessidade de haver canais arejados e efetivos de diálogo entre o cidadão e a Administração Pública. Cada véz mais, se caminha para um direito administrativo de "Estado" e. pois, constitucional, deixando para trás um paradigma de direito administrativo de "Governo". Está-se a preferir o interesse público primário em detrimento do secundário, o que manifestamente não pode prescindir do diálogo entre os diferentes atores da relação estatal. que tem como seu vértice necessário o cidadão. Diálogo este do qual o cidadão foi, por muito tempo, alijado.

Diante deste quadro de alteração do direito administrativo inaugurado pela Constituição de 1988 o processo administrativo ganhal status constitucional, justatmente, por ser via idônea para que se instaure o diálogo entre a Administração Pública e os cidadãos. Mais do que o atendimento do seu caminho lógico, deve a ação administrativa demonstrar que rem a pôr em marcha reclames legútimos que vão ao encontro do interesse público. Nesta quadra. o processo administrativo ganha relevo como forma de legitimação do agir estatal, e, por definição da Constituição, justificação do próprio exercício do "poder". 3 .

Conclui-se, pois, que o processo administrativo, máxime em função de sua índole constitucional, é dos instrumentos mais poderosos para que se tenha um exercício democrático e legítimo do agir estatal. Infelizmente, esta ferramenta é subutilizada, deixando baldo de sentido $ı$ m importante quadrante da Constituição.

Não por outra razão afirmou recentemente o Superior Tribunal de Justiça em acórdão que cuida do tema: ${ }^{4}$ A Lei $9.784 / 99$ é, certamente, am dos mais importantes instrumentos de comrole do relacionamento entre Administraçăo e Cidadania. Seu dispositivos trouxeram para nosso Direito Administrativo, o devido processo legal. Não é exagero dizer que a Lei $9.784 / 99$ instaurou no Brasil, o verdadeiro Estado de Direito."

Neste espírito, um dos pontos que ainda está a merecer análise adequada da doutrina e da jurisprudência é a fixação adequada do âmbito de validade da Lei Federal de Processo Administrativo (LPAF). Não bastasse por si só ser movediço o trato com a referida Lei, razōes de índole constitucional concorrem para o fenômeno

3 Anota sobre o tema MOREIRA NETO. Diogo de Figueiredo: "Com efeiro. a idéia do processo como instramento de legiamaçăo na filosofia moderna, espectialmeme na étic a política. fruto da racionalidade argumentativa. tem merecido a atenção dos mais conspicuos pensadores do Direito contemporâneo." (in Direito Regulatório. Rio de Janeiro: Renovar, 2003, p. 156).

4 STJ, I ${ }^{\star}$ SEÇÃO, MS 8946/DF. Rel Min. Humberto Gomes de Barros, j. 22.10.2003, DJ 17.11.2003. p. 197. 
de sua subutilização; aliando-se à timidez com que se tem manejado a Lei $n^{\circ} 9.784 / 99$, soma-se a própria incerteza que ainda gera o fenômeno da processualidade no âmbito da Administração erigido pela Constituição.

Feito este aparte introdutório, à guisa de estado da arte, cabe justificar minimamente o presente ensaio.

Como já se teve o ensejo de se deixar entrever, o eixo lógico-jurídico que permite elucidar o grosso das dívidas em relação à $L P A F$ reside em seu cotejo com as disposições constitucionais que dão conteúdo e suporte à processualidade administrativa. Destarte, qualquer dúvida em relação aos limites e possibilidades de aplicação da LPAF deve remeter o intérprete, de imediato, ao Texto Magno.

Com este cuidado (ao menos uma pretensão sincera neste semtido), aborda-se questão que se julga fundamental para emprego da Lei. qual seja fixar com acerto o seu âmbito de aplicação.

Para tanto, optou-se por tecer as considerações pertinentes do tema diretamente referidas ao seu art. $1^{\circ}$ fazendo-se assim as ponderações que se julgam necessárias a suportar as inferições havidas, com imediata referência ao enunciado da lei. Este método, se bem que pouco utilizado de forma pontual, tem a virtude de dar maior concretude ao labor teórico que se pretende desenvolver, pois possibilita imediata referibilidade entre as razões da lei e da Constituição, desvelando os aspectos práticos do labor jurídico.

Antes ainda de empreender a análise que se pretende do art. $1^{\circ}$ da Lei $n^{\circ} 9.784 / 00$, necessita-se, ainda que minimamente, fixar o ponto de vista usual acerca da questão que, adianta-se, busca ser refutado nesse ensaio.

A opinião mais difundida acerca do âmbito de aplicação da Lei de Processo Administrativo, fazendo análise meramente gramatical, identifica que esse plexo normativo incide sobre as relações desenvolvidas no seio da Administração Federal direta $e$ indireta. Nada além, nada aquém. ${ }^{5}$

Por fim, em sendo essa a opinião usual acercal do tema, $e$ por manifestamente o presente texto se afastar dessa orientação. cabe desde logo, à moda de José Souto Maior Borges, fazer uma apologia do erro ${ }^{\circ}$ ressalvando de antemão a possibilidade do equívoco. Isso pois, caso não se logre demonstrar nenhuma das propostas ora esposadas, por cedo restará o consolo de ter levado a efeito tentativa sincera de contribuir para a análise do fenômeno "processo administrativu".

Seguindo esta linha, cabe pôr em mira o objeto primeiro do estudo pretendido:

Art. $1^{\circ}$ - Esta Lei estabelece normas básicas sobre o processo administrativo no âmbito da Administração Federal direta e indireta. visando, em especial, à proteção dos direitos dos administrados e ao melhor cumprimento

5 Nesse sentido consultar os comentários ao art. $1^{\circ}$ da Lei Geral de Processo Administrativo na seguinte obra de CARVALHO FILHO, José dos Santos. Processo Administrative Federal ..... comentários à Lei 9.784 de 29.1.1999. Rio de Janeiro: Lumen Juris, 2001, p. 38 e ss.

6 SOUTO MAIOR BORGES, José. Ciência Feliz. 2“i ed, Sĩo Paulo: Max Limonad, 2000. 
dos fins da Administração.

$\$ 1^{\circ}$ Os preceitos desta Lei também se aplicam aos órgãos dos Poderes Legislativo e Judiciário da União, quando no desempenho de função administrativa.

$\$ 2^{\circ}$ Para os fins desta Lei, consideram-se:

I - ólgão - a unidade de atuação integrante da estrutura da Administração direta e da estrutura da administração indireta;

II - entidade - a unidade de atuação dotada de personalidade jurídica;

III - autoridade - o servidor ou agente público dotado de poder de decisão.

Fixado o objeto do estudo. cumpre analisá-lo à luz da Carta Magna, fizzendo releitura dos seus termos e buscando possibilital um novo ponto de vista acerca da matéria. É justamente uma interpretação constitucionalmente conforme do instituto, a única pretensão que se permite nesse artigo.

\section{2 - Comentários ao caput: Âmbito de incidência da lei de processo administrativo - para além da Administraçäo Federal}

Problema sempre tormentoso de hermenêtutica é firmar adequadamente o leque de situações que estão sob a égide da norma interprelada: é un dos problemas clássicos que se põen ao jurista. Imprescindivel, assim, fixar at abrangência da Lei $n^{\circ} 9.784 / 99$, haja vista a leitura usual levar a uma resposta que, crê-se, não se sustenta diante de nosso sistema jurídico, em especial da Constituição Federal de 1988.

O primeiro artigo da lei de processo administrativo federal busca (como tantas outras) determinar o âmbito de aplicação desta lei. Neste passo, a primeira impressão que se extrai do texto é a pretensão de a lei incidir no âmbito da Administração Federal, tanto direta quanto indireta (interpretação gramatical). Esta assertiva é, seguramente, verdadeira, no entanto não responde por completo à questão do âmbito de incidência da Lei $n^{\circ} 9.784 / 99$ e não pode ser lomada de maneira a excluir outras hipóteses.

Superada a óbvia constatação de a lei se aplicar ao ambito federal. cumpre ir além: ou seja, perquirir se a lei teria aptidão para disciplinar situações que, porventura, se desenvolvam além da esfera Federal, no âmbito da Administração Pública Estadual ou Municipal.

Crê-se que a resposta é de todo afirmativa. por contingências de ordem constitucional que passam a ser explicitadas Somente assim podo-se dar trato sistemático ao tema, logrando referir o art. $1^{\circ}$ em nosso sistema constitucional que deu plena guarida ao processo administrativo.?

7 "Todos são iguais perante a lei. sem distinģão de qualquer natureza garantindo-se aos brasileiros e aos estrangeiros residentes no País a inviolabilidade do direito à vida, à liberdade. à igualdade, à segurança è à propriedade nos termos seguintes: (...) aos litigantes, em processo judicial ou administratio. e aos acusados em geral são assegurados o contraditório é a ampla 
Como primeiro argumento a ser alegado em favor da não exclusividade desta lei aplicar-se somente à Administração Federal traz-se a prescrição contida no seu próprio art. $1^{\circ}$, caput, in fine - "(...) visando, em especial, à 'proteção dos direitus dos administrados' e ao 'melhor cumprimento dos fins da Administração'". Necessário, assim, discorrer minimamente acerca dos fins da Administração e do direito dos administrados.

Da mais elementar leitura do art. $37 \mathrm{da} C F / 88$ infere-se que os fins primeiros a que se submete a atividade administrativa revestem-se de hierarquia constitucional e vinculam toda a Administração, seja na esfera de competência da União, seja na dos Estados, Distrito Federal e Municípios. O mesmo fenômeno se dá em relação aos direitos inerentes à qualidade de cidadão administrado que, por serem outorgados pelo Texto Magno, na qualidade de normas centrais estão indenes a qualquat desnaturação mesmo se perpetrada sob a invocação do princípio tederativo

Com efeito, o princípio federativo tem o propósito justamente de garantir o máximo atendimento dos direitos findamentais." A partição constitucional de competências entre os entes federados funda-se na suposição de que diferentes ordens políticas, cada qual ocupando um campo de atuação defïnido (i.e. competência), possibilita um atendimento mais imediato dos direitos fundamentais.

A repartição constitucional de competências contém em seu bojo o ideal de que cada pessoa política tem mais aptidão para concretizar certos valores cuja competência, por esta razão. é a si outorgada pela Constituição. Note-se que há certos valores que, inclusive, devem ser tratados de maneira conjunta para serem concretizados de maneira adequada. $\mathrm{O}$ atendimento dos valores constitucionalmente tutelados é o critério retor da partição de competências federativas engendrada pelo constituinte originário. ${ }^{10}$

Tal conclusão se alcança, especialmente. da análise das competências concorrentes (CF/88, art. 24) que se justificam precisamente sob o influxo dos atrgumentos expostos, na medida em que certos valores, para serem curados de maneira adequada, exigem a composição entre diferentes ordens federativas.

A atribuiçāo de competências distintas entre diferentes éntes féderais näo é am fim que se baste em si, e visa, pois, a garantir o máximo atendimento de valores constitucionalmente tutelados, especialmente direitos e garantias individuais. $\dot{E}$ a legitimação democrática do poder que coloca todo exercício do poder sob o intluxo

defesa, com us meios e recursus at ela inerentes" (CF/88, ant. $5^{\circ} \mathrm{LV}$ )

\& Classificação de MACHADO HORTA, Raul. Estudes de direitu constitucional. Belo Horizonte: Del Rey 1995. p. 390 a 393.

9 Sobre o tema Estado Federativo consulte-se. por referencia obrigatória: MACHADO HORTA, Raul. Op. cit.. p. 345 a 522.

10 Aliás, quer nos parecer que toda partição de competência se dá para melhor altendimento das finalidades que justificam a sua própria existência. Com efeito. o exercicio das competências só se faz legítimo face à satisfaç̧̃o das finnalidades públicas que as justificam, sendo que todo exercício de poder deve orientar-se para este fïm, inclusive as especializações. 
do exercício de uma função. Ou seja, o princípio federativo busca dar guarida também a outros valores constitucionais e existe como maneira de instrumentalizá-los. A repartição federativa de competências é a maneira que o constituinte julgou escorreita para a realização dos diversos fins a serem perseguidos por nosso Estado Constitucional.

As regas contidas na Lei de Processo Administrativo claramente buscam garantir $o$ atendimento dos fins da Administração e os dircitos dos administrados; ambos os conceitos revestem-se de dignidade constitucional e, não só podem, como devem, ser concebidos de maneira parelha en toda nossa Federação. Com efeito. esse condicionamento se impõe até em face do exercício das competênciats federativas que, quando exercidas, devem guardar respeito a essals balizas. Não se concebe que qualquer ente da Federação venha a exercer suas competências descurando dos valores: direitos dos administrados e finalidades da Administração.

Não haveria sentido em se conceber que os fins da Administração Pública no Estado do Sergipe ou no Município de Curitiba fossem outros senão os mesmos fins da Administração Federal, tudo em conformidade e na acepção empregada pelo art. $37 \mathrm{da} \mathrm{CF} / 88$.

Também seria inviável considerar que os direitos conferidos aos cidadãos inerentes a esta qualidade. quando no trato com a Administração Federal. fossem diversos dos que lhes são conferidos quando jungidos à esfera Estadual ou Municipal.

Tanto os princípios que sujeitam a ação administrativa, quanto os direitos dos cidadãos, são conformes ao longo de toda nossa Federação na medida em que esse termo for buscado na Constituição e na medida em que as diversas pessoas políticas só legislam em atenção, e dando guarida, a tais predicados.

Ou seja, há um mínimo conferido pela Constituição que nâo está sujeito ạ temperamentos, caracterizando o "núcleo duro" de nossal função administrativa, que é definido pela própria Carta Magna e implica em respeito aos direitos dos cidadãos e às finalidades da Administração.

Com a assertiva não se pretende negar dignidade às contingências de nosso esquema federativo e à possibilidade de haver regramentos distintos concebidos por diferentes pessoas políticas. Apenas se explicitam os eixos de sua racionalidade, conferidos pela própria Constituição Federal. Cumpre explicitar melhor a idéia.

Com efeito, os diferentes âmbitos onde se concebe o exercício de função administrativa (União, Estados, Distrito Federal e Municípios) e se reconhece inclusive capacidade para legislar acerca de direito administrativo. devem guardar no exercício dessas funções estreita consonância com a Carta Magna. Pode-se dizer mais.

O exercício destas competências só se fáz legítimo em se atendendo rigorosamente as contingências de ordem Constitucional, que fixam os valores ótimos do sistema, a serem perseguidos e concretizados pelas diferentes ordens legais. Neste passo, só tem sentido o exercício das competencias legislativas (e sua própria repartição federativa) para integrar e efetivar os valores postos pela ordem constitucional que são os vetores que condicionam todo o agir estatal (nas funções de administrar, julgar e legislar). 
Pesquisa mais minuciosa empreendida no nosso sistema Constitucional é necessária para que se fixe o regime que a Constituição outorgou ao "processo administrativo" à guisa de definir seu âmbito de incidência. Para tanto, mister enunciar de plano o conteúdo que os princípios da ampla defesa e do contraditório (direitos fundamentais) assumem em nosso Estado (concebido como República Federativa):

Art. $5^{\circ}$ - Todos são iguais perante a lei, sem distinção de qualquer natureza, garantindo-se aos brasileiros e aos estrangeiros residentes no País a inviolabilidade do direito à vida. à liberdade, à igualdade, à segurança e à propriedade, nos termos seguintes:

(...)

LV - aos litigantes, em processo judicial ou administrativo, e aos acusados em geral são assegurados o contraditório e ampla defesá. com os meios e recursos a ela inerentes; (grifou-se).

Numa primeira aproximação com o conteúdo da norma constitucional que garante o contraditório e a ampla defesa aos litigantes e acusados, é de se ressaltar, fazendo-se o necessário cotejo com o cuput do artigo $5^{\circ}$, que não há discriminação no seio da Federação possível de ser levada a cabo de maneira constitucionalmente eficaz no que tange ao exercício destes direitos.

Ou seja, não hão de se operar, no que toca à integridade do contraditório e da ampla defesa (i.e. em relação ao processo), distinções de natureza alguma entre brasileiros, por toda a Federação, e estrangeiros. Todos fazem jus a ser tratados de maneira integra, sendo-lhes garantido o devido processo legal onde quer que se encontrem. Com efeito, contraditório e ampla defesa devem sempre ser franqueados quando se estiver a tratar de processo. Veja-se que tais conceitos condicionam todo o exercício do poder público; não só a Administração, mas também o exercício das funções legislativa e judicial.

Como primeira premissa, fixe-se que não há possibilidade de se conceber duas maneiras distintas de se operar o devido processo legal em nossa Federação. Sequer a alusão ao princípio federativo (como pretendido na Lei) teria o condão de alterar esta constatação, pois revestida da mais alta índole constitucional. A garantia é íntegra e não pode ser alijada em seu conteúdo, vinculando todas as pessoas políticas que integram nossa Federą̧ão ao seu pleno atendimento.

O devido processo legal, quer seja no processo administrativo, quer seja no judicial não pode ser concebido de maneira diversa em duas entidades políticas distintas. Repisando a célebre lição de Celso Antônio BANDEIRA DE MELLO, invocando a Constituição, não há motivo jurídico apto a legitimar este discrímen."

Resta, pois, a perplexidade da enunciação clara contida no caput do art. $1^{\circ} \mathrm{da}$ Lei $n^{\circ} 9.784 / 99$ que afirma que a Lei "estabelece normas básicas sobre o processo administrativo no âmbito da Administraçâo Federal". Cabe, pois, buscar fixar a amplitude a ser dada ao tema em estando minimamente explicitada a impossibilidade

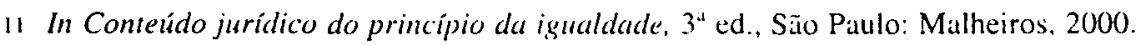


de se conceber ampla defesa e contraditório de maneira diversa ao longo de nossa Federação.

\section{2 - Distinção entre processo e procedimento como pressuposto necessário} para fixação da incidência da LPAF e suas contingências

Para que bem se possa compor a questão e dar sentido à prescrição inaugural da Lei $n^{\circ} 9.784 / 99$ é necessário fixar, por imprescindível, a distinção entre processo e procedimento, distinção que, aliás, estribará o grosso das posições que serão adotadas no presente trabalho. Por vezes tomada por inútil, crê-se que apenas a diferenciação entre os dois institutos permite fixar com propriedade o âmbito de incidência da Lei $n^{\circ} 9.784 / 99 .^{12}$

Na raiz da distinção proposta está a própria prescrição do inc. LV do ant. $5^{\circ}$ da CF/88 que identifica o fenômeno "processo" com a existência de "litigantes" e "acusados".

A prescrição une, pois, o devido processo legal (i.e. ampla defesa mais contraditório) à situação de conflituosidade entre os cidadãos e a Administração. Assim sendo, o processo é fenômeno que se junge de maneira indelével à noção de ampla defesa e contraditório assegurado a litigantes e acusados. Onde houver litigantes e acusados, surgirá o fenômeno do processo com suas garantias.

Caracteriza-se o processo como instituto jurídico qualificado pela necessidade de se assegurar a ampla defesa e o contraditório em face de situações de conflituosidade.

Processo administrativo pressupõe, destarte, a contraposição entre interesses; caso faleça esta nota de conflituosidade não se poderá denominar a relação havida de processo, conforme a acepção que lhe emprega a Constituição.

Tal constatação é de fácil verificação no âmbito da função judiciária, reconhecendo-se a qualidade de litigantes (ou acusados) às partes contendoras, sendo incontestável seu direito ao devido processo legal. Ninguém terá dúvida. v.g., em afïrmar a absoluta nulidade de uma sentença que cercear o direito à prova de uma das partes ou que não a chamar ao processo de maneira eficaz. Não há problemas para que se admita a absoluta inaptidão de se reconhecer autoridade pública ao ato estatal que se pratique sem observância do contraditólio e da ampla defesa. caso se esteja a exercer função jurisdicional.

Contudo, tal percepção é mais nebulosa em relação do exercicio da função administrativa, por razões eminentemente históricas, onde as situações de conflituosidade havidas entre Administração e cidadãos foram sempre, de hábito, chamadas de "procedimento". Impende fixar a acepção do fenômeno sob o sistema da Cons-

12 No sentido de ser indiferente a distinção ora levada a efeito, consulte-se: SUNDFELD, Carlos Ari. Processo e procedimento administrativo no Brasil in As Leis de Processo Administrativo Lei Federal $9.784 / 99$ e 10.177/98. São Paulo: Malheiros. 2000. especialmente a nota n 5 nas p. 19 e 20 . 
tituição para que a dúvida terminológica não passe a ser de conteúdo e acabe por gerar angustiamento de direitos/garantias fundamentais.

O que não se pode admitir (como infelizmente se vê) é que o rótulo "procedimento" leve à insustentável conclusão de que, no seio da Administração, em se verificando "conflituosidade", esteja dispensado (ou abreviado) o devido processo legal e as garantias a ele inerentes, podendo haver o exercício de função administrativa que não atenda aos requisitos da ampla defesa e do contraditório.

A distinção não é meramente terminológica e o fenômeno processo no seio da Administração não se confunde com procedimento. ${ }^{13}$ São maneiras radicalnente distintas do exercício das competências conferidas à Administração. A racionalidade entre as duas maneiras de atuar não pode ser confundida. sob pena de grassar a perplexidade e não se dar resposta adequalda ao alcance da LPAF.

Neste sentido, aliás, vêm se pronunciando alguns autores, nada obstante estar longe de ser pacífica a distinção como aqui proposta. ${ }^{14}$ Romeu Felipe Bacellar, após fazer profunda análise nas letras jurídicas pátrias e estrangeiras acerca dos dois fenômenos, logra explicitar o que se entende por processo na seara administrativa com (de acordo com a linha ora adotada) absoluto rigor:

"Quando à competência adiciona-se a colaboração de sujeitos e contraditório, o procedimento expressa-se como processo. O processo administrativo é forma de exteriorização da função administrativa qualificado pela participação de interessados em contraditório, imposto diante da circunstância de se tratar de procedimentos celebrados em preparação a um provimento (ato de poder imperativo por natureza e definição), capaz de interferir na esfera jurídica das pessoas." 15-16

Do que se expôs, já se está a notar que o processo e o procedimento são realidades distintas, sendo que a noção de processo, onde quer que ele se manifeste, vincula-se (por injunção constitucional) à litigiosidade havida entre os sujeitos contendores, condição que, se verificada, thes garante a ampla defesa e o contraditório.

Tanto o processo como o procedimento estão compreendidos no hiato lógico havido entre a existência prévia de um competência ( $\mathrm{e} o$ ato concreto praticado no

13 Este pressuposto é tomado como "condição geral estipulativa". sem o qual sequer é possível tratar do fenômeno do processo no seio da Administração na obra que desde já indica-se como referência indispensável, de BOCKMANN MOREIRA, Egon. Processo Administrativo princípios constitucionais e a Lei 9.784, São Paulo: Malheiros, 2000.

14 Para uma crítica profunda em relação à posição adotada e, como de estilo, incisiva consulte-se por todos JUSTEN FILHO, Marçal. "Consideraçōes sobre o processo administrativo fiscal" in Revista Dialética de Direito Tributário, n 33, 108.

15 BACELLAR, Romeu Felipe. Princípios constitucionais do processo administrativo disciplinar, São Paulo: Max Limonad, 1998, p. 48.

16 Ainda, no mesmo sentido consulte-se a opiniāo da Lúcia Valle Figueiredo, Curso de Direito Administrativo, $3^{\circ}$ ed, São Paulo Malheiros, especialmente p. 379 e ss. 
exercício desta competência. Contudo, isso não está a autorizar confusões terminológicas ou de conteúdo.

Pode-se dizer que ambos os fenômenos tratam da passagem de um plano abstrato gizado por norma para um plano concreto de atuação da Administração; no entanto, quando há litigiosidade, há exigência de se passar pelo crivo do contraditório e da ampla defesa, para a prática do ato. Em ambos os casos (processo e procedimento administrativo) haverá a prática de um ato administrativo ao fïm; porém no caso de este ato compor uma situação de litigiosidade ele deverá ser praticado sob a forja do devido processo legal, agregando essa condição para sua perteição.

A dissimilitude entre os dois institutos situa-se, fundamentalmente, em relação a como se exercerá esta passagem, ou seja, quais os requisitos para que o ato final cumpra seus pressupostos e seja reconhecido como perfeito.

No procedimento, por falecer a nota de conflituosidade, não há necessidade de a Administração ater-se necessariamente às lazões do cidadão, considerando-as expressamente (i.e, sob a pauta do contraditório) para proferir decisão. $\mathrm{O}$ ato final somente precisa atender os interesses da Administração defïnidos em lei, o que se dá pelo atendimento da forma escorreita para sua produção, bem como do atendimento inegociável das finalidades públicas defïnidas na lei e na Constituição.

No processo, haja vista a nota de conflituosidade havida, é imprescindível que o ato final a ser praticado (que póe fïm, no seio da Administração, ao conflito) possibilite a efetiva participação do cidadão. Precisamente, há de se reconhecer o ato final do processo como um ato que encerra um conflito, e por isto não prescinde de fazer valer as razões de ambas as partes, sopesando-as, para que seja produzido de forma juridicamente legitima. ${ }^{17}$ Aí, pois, reside a importância de se explicitar a identificação feita pelo Texto Magno entre o processo como fenômeno qualificado pela conflituosidade.

É a conflituosidade (seja por haver litigantes, seja por haver acusados) que torna imperativo dar possibilidade a ambas as partes manifestarem-se para a produção do ato final, pois é este ato final que comporá, no plano jurídico, a divergência. Romeu Felipe Bacellar, novamente, manifesta-se com clareza a respeito desta exigência:

“( ... ) o sentido reside na identificação de sujeitos processuais - litigantes e acusados — os quais, através do processo participam da elaboração do provimento final, atingidor de suas esferas juridicas. Os litigantes e acusados são sujeitos processuais e não meros objetos ou espectadores, receptores passivos da decisão pronta, sem chance de participar." 18

17 A nota característica do conflito jurídico se vincula à idéia de que na multiplicidade de mensagens transmitidas pelo direito pode haver deficiência na sua transmissão, gerando expectativas frustradas perante às mensagens que o direito assume como válidas. É o magistério de FERRAZ JÚNIOR, Tércio in Direito, retórica e comunicação, 2 " ed., São Paulo: Saraiva, 1997.

18 Op. cit., p. 67 
É lídimo, pois, afirmar que a distinção que separa o ato administrativo praticado ao fim de um procedimento e o que se pratica ao fim de um processo é essencialmente de regime jurídico, pois, não se concebe processo sem contraditório. ${ }^{19}$

Complementando a idéia, cabe perquirir quando é que exige nossa Constituição o processo, ou seja, quando é que se exige o atendimento do contraditório e da ampla defesa para que se exerça a função administrativa.

Elucidativa a prescrição constitucional que enuncia: "ninguém será privado da liberdade ou de seus bens sem o devido processo legal" (CF/88, art. $5^{\circ}$, inc. LIV).

Com efeito, o processo é imprescindível para que se manifeste qualquer ato estatal concreto ${ }^{20}$ tendente a interferir tanto no patrimônio jurídico dos cidadãos (liberdade e propriedade). ${ }^{21} \mathrm{Na}$ dicção elegante e sintética de Marçal JUSTEN FILHO: $: 2$

"A invocaçāo constitucional do art. 5", inc. LV, impôs a observância de um devido processo na via administrativa. Assegurou-se as particulares o direito à ampla defésa. coma garantia inafastálel do contraditório. Tomouse fora de divida que a decisão administrativa, sempre que for apta a produzir o sacrificio de interesses ou direitos privados, deverá ser o resultado de um procedimento administrativo, respeitado o principio do contraditório".

19 No mesmo sentido dos autores ora mencionados, em relação à dicotomia processo/procedimento, levando a análise às minúcias do direito tributário, em obra sem par no nosso direito pátrio, consulte-se: MARINS, James. Direito processual tributário brasileiro (administrativo e judicial), $3^{3}$ ed., São Paulo: Dialética, 2003.

20 Diz-se ato concreto, para afastar a idéia de lei (em sentido amplo) que é ato estatal abstrato e genérico que não interfere na esfera jurídica dos cidadãos e sim, verdadeiramente, a define.

21 Acerca da extensão a ser dada ås vocábulos liberdade e propriedade, como motores do devido processo legal, é de se ver que esses termos nāo comportam leitura estrita e sim visam à definição da esfera jurídica legitimamente protegida dos cidadãos. Elucidativa neste particular a tradição americana do "due process of law", que mesmo o identificado textualmente, conforme a $5^{\text {a }}$ e a $14^{4}$ Emendas, com a proteção da vida, da liberdade e do patrimônio reconhece a necessidade da observância do devido processo legal quando houver exercício da atividade do poder público sujeitando a esfera jurídica (individual) dos cidadãos. São tais procedimentos chamados de "administrative adjtadication" e o seu sentido não se esgota na proteção da vida, da liberdade è do patrimônio. Para uma análise detida do exposto acerca do direito norte-americano, da onde refiraram-se estas idéias, consulte-se: SCARPINELLA BUENO, Vera. Devido Processo Legal e a Administração Pública no Direito Administrativo Norte-A mericano - Uma breve comparação com o caso brasileiro in Devido Processo Legal na Administração Pública, coord. Lúcia Valle Figueiredo, São Paulo: Max Limonad, 2001, p. 13 a 79.

22 "Considerações sobre o processo administrativo físcal" in Revista Dialética de Direito Tributário, $n^{\circ} 33,108$. Ressalvamos. contudo, com o máximo acatamento, nos termos já expostos, discordância acerca da consideração do autor de não haver um processo administrativo propriamente dito, sob o fundamento de que o fenômeno processo cinge-se à jurisdiçāo, necessariamente, haja vista ser seu elemento ôntico, a relação triangular (autor, juiz e réu), que faleceria nas lides administrativas. 
Neste passo, e indo além no conceito, pode-se dizer que o fenômeno processo administrativo conecta-se com a própria correição do desempenho da função administrativa que deve guardar conformidade com o patrimônio jurídico dos cidadãos. não se tolerando qualquer intervenção que seja desproporcional. Va lição de Vera Scarpinella Bueno: ${ }^{23}$ "O relevante, hoje, é focar o devido processo na ação governamental e na sua necessária razoubilidade, independentemente da qualificação jurídica do direito violado."

Se obviamente o particular não pode pretender interferir no patrimônio de outro sem atentar às garantias do devido processo legal (garantida pela chancela indefectível do Judiciário), também não pode pretender a Administração Pública interferir na esfera jurídica dos cidadãos sem que lhes garanta o devido processo legal. A posição da Administração Pública e suas prerrogativas (donde destacamos a autoexecutoriedade) não rende ensejo para que se rompa com o devido processo legal, caso se verifique a litigiosidade.

Não há posição de supremacia (em nome de interesses públicos) que possa fazer a Administração se arvorar da faculdade de não ofertar o devido processo administrativo. Sem medo de repetição, não está o comando constitucional sujeitos a temperamentos de qualquer ordem, mesmo os advindos de invocações da supremacia do interesse público sobre o privado.

O Texto Magno exige que quando, exercite a Admmistraçào determinada competência e tal manifestação implique em ingerência no patrimônio e na liberdade dos cidadãos (i.e. patrimônio jurídico), o ato produzido não se dê por simples procedimento. mas por processo se assim o reclamar o administrado. No momento em que houver a contraposição de interesses entre Administração e cidadãos deverá surgir o processo com todas as suas garantias.

A distinção demonstra sua pertinência pois no primeiro caso não é necessário (conquanto seja facultado) conferir ao cidadão a ampla defesa e o contraditório e no segundo sim. Com efeito, quando o ato a ser produzido implicar em disposição por parte da Administração do patrimônio e da liberdade dos cidadãos, é de manifestar esta competência sob a pauta do processo.

O procedimento indica a maneira como irá se operar a manifestação do exercício do poder público. colocando-o dentro de uma pauta racional e, pois, controlável. A procedimentalidade é ínsita ao agir do Estado. Não há de se conceber que possa vir a agir o Estado em desconformidade com o procedimento que the é imposto pela Lei. Isto por elementar contingência da própria noção de agir estatal, que pressupõe 0 atendimento de finalidades necessariamente públicas e necessariamente sindicáveis. O procedimento - inimigo do arbítrio - é a garantia máxima do controle da Administração.

O processo, para além de indicar como se manifestará o Poder Público, cumpre a função de fazer garantir que o cidadão fará constar suas razões na manifestação do Poder Público que the toque a esferat jurídica mais íntima. O ato que tradu< $u$ 
exercício do poder público no que tange à liberdade e ao patrimônio não pode prescindir de garantir a possibilidade de manifestação do cidadão, e sua juridicidade está condicionada a que se franqueie ao administrado a oportunidade de tomar parte da feitura do ato final.

Enunciando com simplicidade, o comando constitucional impõe que se ouça (ou se dê possibilidade de fazê-lo) o cidadão e se avaliem suas alegações sempre que o Estado pretenda adentrar sua esfera juridica no que toca à liberdade é ao patrimônio.

Voltando à pesquisa do âmbito de aplicação Lei n $9.784 / 99$, cabe consignar a utilidade da distinção. Antes, ainda, faz-se necessário meditar sobre mais uma disposição constitucional. Cabe, pois. lançar olhos sobre a competência legislativa em matéria processual e procedimental:

Art. 22 - Compete privativamente à União legislar sobre:

I - direito civil, comercial, penal, processual. eleitoral, agrário. marítimo, aeronáutico, espacial e do trabalho; (destacou-se em itálico).

Art. 24 - Compete à União, aos Estados e ao Distrito Federal legislar concorrentemente sobre: (...)

XI — procedimentos em matéria processual: (destacou-se em itálico).

Da análise dos dispositivos que traçam a competência em matéria de processo e em matéria de procedimentos, nota-se que para a Constituição processo e procedimento são realidades inconfundíveis. Pensar de maneira diversa, tomando os vocábulos como sinônimos no plano administrativo, seria anular a inteligência da norma que atribui privativamente, legislar sobre processo, à União.

Se há na Constituição menção tão expressa afïrmando que processo e procedimento são realidades distintas (separada pela divisão de competências legislativas), é preciso perquirir qual o sentido que a própria Constituição atribui a tal diferença. Não comporta dúvida que a Constituição concebe conceitos distintos de processo e procedimento, senão não haveria sentido na atribuição de competências a pessoas políticas distintas.

Volvendo ao que se disse, é preciso encarar o processo como instituto vinculado a situações de conflituosidade, enquanto o procedimento vincula-se ao exercício da função pública (dinamização de competência previamente atribuída).

Ferindo a questão por outra banda, é de se pôr em mira o porquê de a Constituição atribuir à União competência privativa para legislar sobre processo e não sobre procedimento. Novamente, é a posição do devido processo legal enquanto garantia inalienável do cidadão (art. $5^{\circ}, \mathrm{LV}$ da $\mathrm{CF}$ ), que tem o condão de aclarar o tema.

Isto pois, afigura-se inconcebível em nosso esquema federativo que questão deste jaez pudesse receber tratamento diverso em diferentes entes tederatrus.

Referindo a questão sob o prisma do processo administrativo, objeto imediato deste estudo, pensar que em diferentes quadrantes da Administração pudessem ser 
concebidos diferentes processos administrativos (na acepção em que a Constituição emprega o termo) seria negar a unidade constitucional do processo.

No que toca a assegurar-se o contraditório, a ampla defesa com os meios $e$ recursos a ela inerentes, há de se respeitar a unidade constitucional. Isso não significa negar em absoluto a competência de outros entes federativos para legislar sobre o tema, conquanto tratem de procedimento, ou impingir a pecha de nulidade a procedimentos especificos regulados por leis próprias que visam a resguardar especificidades de setores unde hajam particularidades.

A distinção entre processo e procedimento é pressuposto para que se fixe o âmbito de alcance da lei, não só por ser inconcebível pretender que se dê trato distinto ao devido processo legal em diferentes entes federativos, mas também por ser explícita a atribuição privativa da União para legislar sobre processo. conceito que se reveste de conteúdo próprio na Constituição.

Como visto, processo - para a Constituição Federal - assume significação diametralmente oposta de procedimento, submetendo a Administração. quando no exercício das competências que the são atribuída a um regime jurídico diverso. Regime que se qualifica pela necessária participação do cidadão (ampla defesa e contraditório) para produção do ato final (terminativo da conflituosidade).

Ao atribuir competência à União para legislar sobre processo, e alo ter fixado o concedo ao atendimento efetivo da ampla defesa e do contraditório, infere-se que a descrição legislativa que venha a concretizar o devido processo legal valha para toda a Federação.

Isto, por conta de duas conclusões inesquiváveis que se haurem da Constituição: (i) dignidade constitucional do processo administrativo e (ii ) reconhecimento da distinção entre processo e procedimento, inclusive quanto ao exercício da competência legislativa. Postos estes aclaramentos, cabe fazer breve síntese das idéias expostas explicitando o âmbito de aplicação da Lei $n^{\circ} 9.784 / 99$, consoante as premissas que se traçaram.

2.3 - Fixação do alcance da Lei e interpretação possível da reserva Federativa do seu art. $1^{o}$, caput

Finalmente, cabe pôr em elenco mais sistemático as considerações acima expendidas para que se fixe o âmbito de incidência da Lei $n^{\circ} 9.784 / 99$, que. como visto, vai mais além do que o âmbito da Administração Federal.

Como visto, o primeiro predicado metodológico a ser reclamado do intérprete quando do trato com o diploma legal é que seja feita a distinção entre processo e procedimento. Em verdade, nem todas as regras (produtos da interpretação) contidas na lei vão se orientar à prática de atos terminativos de conflitos e, pois, nem todas as prescrições representam regras de processo administrativo, consoante aqui definido. 24

24 Aliás, o tenômeno de uma mesma lei conter normas de cariter distinto não é propriamente uma novidade no direito administrativo. É o que se passal, por exemplo, com a identificação das regras 
Isto é, na Lei $n^{\circ} 9.784 / 99$ estão contidas regras de processo e procedimento e sua identificação é que comanda a sua aplicação escorreita.

Primeiramente, cumpre consignar. até pelo tudo o que se expôs, que as regras da Lei $n^{\circ} 9.784 / 99$ que tocam ao instituto "processo" devem ser aplicadas em todos os quadrantes da Administração.

Onde se identificarem as regras da LPAF com o atendimento do contraditório, da ampla defesa e as garantias a ela inerentes, há de se aplicá-las, sem qualquer sorte de reserva em função de não se poder negar ao cidadão as garantias do devido processo legal. 25

Não se trata neste caso de extensão analógica, principiológica, aplicaçĩo subsidiária, supletiva ou coisa que o valha; as regras da lei de processo administrativo aplicam-se diretamente ao âmbito Distrital, Estadual ou Municipal quando se tratatrem de regras de processo.

Na doutrina, sustentam Nelson Nery Júnior e Rosa Maria de Andrade Nery que a aplicação das normas principiológicas da LPAF teriam aplicação imediata para além da esfera Federal e que as normas gerais aplicar-se-iam em caso de lacuna nas leis que disciplinam processos específicos. ${ }^{26} \mathrm{Sem}$ embargo deste ponto de vista, crê-se que o fenômeno é diverso.

Não é pelo fato de as normas serem principiológicas ou pelo fato de serem gerais que se aplicará a Lei $n^{\circ} 9.784 / 99$ a hipóteses que vio além du ámbıtu Federal. Esta aplicação é regida pelo critério constitucional. Não é qualquıer juízo em relação à estrutura da norma que rege a aplicação da Lei $n^{0}$ 9.784/99 além do âmbito Federal. É, sim, o simples fato de se identificar uma regra como garantidora do devido processo administrativo.

Ou seja, quando as regras da LPAF forem normas processuais (garantam o devido processo administrativo) elas devem ser aplicadas, não por serem gerais ou principiológicas, mas por serem elas que garantem a efetivação dos comandos indefectíveis da Constituição atendendo à competência legislativa para tanto.

da Lei Geral de Licitações que assumem o caráter de "normus gerails". que condicionam à sua observância todos os entes federativos e as normas que não se revestem desta naturęa que podem ser alteradas pelos Estados, Municípios e Distrito Federal. E o que Marçal Justen Filho chama de "questão topológica" (in Comentários à Lei de Liciaç̧ão é contralos administrativos. $d^{\text {kt }}$ ed, São Paulo: Dialética, 2.002, p. 15).

25 Cumpre fazer ressalva em face de normas específicas que neste caso terĩo precedência nos termos da LPAF, art. 69. Contudo, é de se dizer que não é a mera existência de lei específica em relação a um tema, que fixe normas acerca de um determinado prociesso, yue governa a dispensa da aplicação das normas previstas na lei geral há de ser levado a efeito minudente juízo de compatibilidade e aplicar-se-a a LPAF em tudo aquilo que não houver norma específica em sentido diverso. É a opiniāo de SUNDFELD, Carlos Ari in As Leis do Processo Administratiso - Lei Federal 9.784/99 e Lei Paulista 10.177/98. Processo e procedimento ádministrativo no Brasil. São Paulo: Malheiros. 2.000, p. 27.

26 NERY JÚNIOR. Nelson e NERY, Rosa Maria de Andrade. Código de processo civil comentado e legislação processual civil extravagante èm vigor. 6 ed., Sĩo Paulo: RT, p. 1.437 (comentários ao art. $1^{\circ}$ da Lei 9.784 ). 
O exercício por parte da União da sua competência privativa para legislar sobre processo, vincula a aplicação direta da Lei $n^{\circ} 9.784 / 99$ em todos os niveis da Administração Pública, quando se identificarem suas prescrições como sendo relativas a processo, ou seja, quando estas regras cuidarem de garantir ao cidadão contraditório e ampla defésa.

Porém. para que não quede vazia de sentido a restrição enunciada no art. $1^{\circ}$, que limita a aplicação da Lei ao âmbito da Administração Federal, é necessário buscar o sentido possível que ela pode assumir. Neste passo, impende dizer que as regras que tratarem de procedimento (enquanto exercício de competência sem necessário atendimento da participação do cidadão) devem vincular apenas a Administração Federal.

Apenas neste caso (regra de procedimento) faz sentido a enunciação do princípio federativo para legitimar a aplicação restrita da Lei de Processo ì Administração Federal. Neste caso, cumpre dizer que não poderia de maneira al guma a lei editada pela União dizer como se procederá o exercício da função administrativa nos outros escaninhos da Administraçăo. A autonomia dos entes da Federação não admite esta sorte de ingerência, sendo que a elas incumbe tratar de como exercerão sua função administrativa.

Enfim. em rasa síntese. no que tange às regras de processo, "Léi "n" 9.784/99 deve ser aplicada a todos os quadrantes da Administração Pública e. no que toca

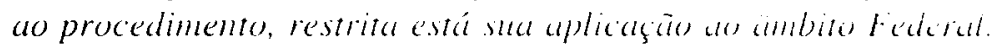

\section{3 - Comentários ao $\$ 1^{\circ}$ : Do exercício da função administrativa como critério de fixação da incidência da Lei n $9.784 / 99$}

O parágrafo primeiro da LPAF trata de dizer que mesmo para além da Administração Pública aplicam-se suas previsões quando haja o exercício da função administrativa no seio dos Poderes Judiciário e Legislativo.

Além do didatismo da proposição, encerra-se em seu bojo conceito dos mais importantes. Note-se. que a incidência da Lei está jungida ao exercício da função administrativa, conceito este, hoje, por estrutural, imprescindível para compreensão do próprio direito administrativo.

Pode-se definir por função, em direito, a necessária relação ao atendimento de interesses alheios quando no exercício de uma prerrogativa. O fato de haver prerrogativas em si não diz nada: o que se põe em mira é que elas estejam a atender um fim que é alheio ao seu titular. É o legítimo atendimento de finalidades alheias ao detentor da prerrogativa a nota essencial da função. É o próprio dever de dar guarida ao interesse de outrem que legitima haver prerrogativas.

Outro não é o fenômeno que caracteriza o direito administrativo ${ }^{27}$, onde todas as prerrogativas que se concedem à Administração visam a atender finalidades

27 Sobre o tema, por inexcedivel, consulte-se: BANDEIRA DE MELLO, Celso Antônio. Discricionariedade e controle jurisdicional, $2^{a}$ ed.. São Paulo: Mallhciros, 1993, em especial o cap. II. 
públicas. Ou seja. as prerrogativas da Administração hão de ser manejadas sempre colimando o atendimento de finalidades públicas, que por vezes não se confundem com os seus próprios interesses. Ousa-se dizer que justamente a fixação da incidência do regime jurídico administrativo é a chave de abóboda para compreender a função administrativa, compreendendo dialeticamente o regime de prerrogativa e sujeições, enfim, compreender o próprio direito administrativo. ${ }^{2 x}$

Trazem-se estes conceitos haja vista seu manifesto valor metodológico quando do trato com a LPAF, justamente auxiliando a determinar seu âmbito de incidência. Para mais que buscar fixar se determinada atividade está contida ou nĩo neste art. $1^{\circ}$ em função do sujeito que pratica o ato e está a exercer competência, deve se perguntar se há o exercício de função no caso em análise: se a resposta for positiva, necessariamente - lembrados os temperamentos feitos acima - aplicam-se as disposições contidas na Lei.

Em síntese, onde manifestar-se função administrativa aplicar-se-ão os preceitos da Lei $n^{\circ} 9.784 / 99$, com as ressalvas feitas ao se comentar o caput do presente artigo.

\section{4- Comentários ao §2": Impossibilidade de se determinar a incidência da LPAF exclusivamente pelo critério orgânico ou subjetiv'o.}

Por fim. seguindo em seu didatismo. classifica a Lei o que se entenderá por órgão, entidade e autoridade. Cumpre, antes de analisar estas categorias, fazer advertência vestibular. Note-se. inicialmente, que para os fins da Lei não se adota classificação em tela como sendo absolutamente rígida podendo levar o interprete à tentação de restringir a aplicação da Lei $n^{\circ} 9.784 / 99$ em função dos critérios subjetivos lá definidos, tomando-a por exaustiva.

Define o Decreto-Lei $n^{\circ} 200$, de 25.06.1967, em seu art. $4^{\circ}$, os entes que compõem a Administração Pública, subjetivamente considerada. ${ }^{24}$ Trata este diploma da Administração direta (sérviços integrados na estrutura administrativa) e da

28 Novamente torna-se imperioso citar: BANDEIRA DE MELLO. Celso Antônio. Curso de direilo administrativo, 14* ed.. São Paulo: Malheiros. 2002. fundamentalmente o Cap. I. donde se extrai a elucidativa passigem yue demonstra a utilidade de adutar estes primados como mótudo de trabalho, em função de seu elevado valor metodológico: "O sistema de ama disciplina juridica. sét régime. portanto, constitui-se do conjunto de principios que the dion especificidade em relaçä ao regime de outras disciplinas. Por conseguime, todos us institutus que abarca - a moda do sistema solar dentro do planetário - articulam-se, gravitam, equilibram-sé. em finç̧ăo da racionalidade própria deste sistema especifico. segundo as peculiaridades que delinciam o regime (no caso, o adminis-

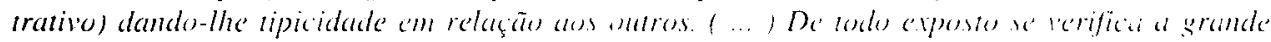
importância da noção de regime administrativo. cajo desenvolvimento purmenorizado é o objeto deste próprio ramo do direito" (in p. 63 e 64 ).

29 Art. $4^{\circ}$ A Administração Federal compreende: I - A Administração Direta que se constitui dos serviços integrados na estrutura administrativa da Presidencia da República e dos Ministérios.

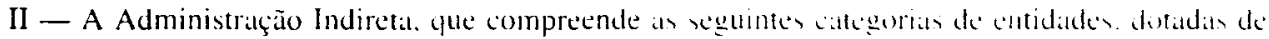
personalidade jurídica própria: a) Autarquias: b) Empresas Públicas: c) Suciedades de Economia Mista.( ... ) (Preservou-se a redação original). 
indireta (entidades personalizadas) composta por: a) Autarquias: b) Empresas Públicas; c) Sociedades de Economia Mista e c) Fundações Públicăls. ${ }^{30-31}$. A alusão à Administração direta e indiretal consta também do caput do art. $1^{\circ}$ da Lei 9.784/99.

Por seu turno, a previsão do $\$ 2^{\circ}$ trata de mencionar nos incs. I e Il o que se compreende por órgão e por entidade, distingüindo-os em função da sua personalização ou não.

Nota-se. destarte. que a classificação subjetiva referente à atividade administrativa não é estranha à Lei de Processo Administrativo, haja vista em seu art. $1^{\circ}$ constar referência à Administração direta e indireta (caput) e aos fenômenos da desconcentração $\left(\$ 2^{\circ}\right.$. I - órgão) e da descentralização (\$ $2^{\circ}$ I - entidade). Contudo, esta classificação não esgota o fenômeno da incidência da Lei no $9.784 / 99$, aplicando-se a Lei exclusivamente em função dos sujeitos integrantes da Administração direta e indireta (cf. Decreto-Lei 200 de 1967).

$O$ critério de incidência da Lei $9.784 / 99$ é material e exsarge em funçäu do exercicio de função administrativa, mesmo que para além das previsöes expressas deste $\$ 2^{\circ}$.

Ao fixar o que se compreende por órgão, entidade e autoridade e as categorias integrantes da Administração direta e indireta, não se está a restringir a aplicação apenas ao que possa imediatamente ser identificado com estas figuras. Isto porque $a$ incidencia da Lei $9.784 / 99$ rege-se pelo exercício da funçāo administrativa. É este o único método de trabalho idôneo a explicitar com precisão a incidencia da Lei.

Assume relevo tal advertência pois as prescriçón contidas no $2^{\circ}$ so podem ser compreendidas sob este enfoque, não cabendo qualquer reducionismo em função exclusivamente do critério subjetivo que é meramente auxiliar.

Pensar de modo diverso seria o angustiamento da dignidade constitucional do processo administrativo que se faz imperativo quando da prática de atos que possam importar em interferência do patrimônio jurídico dos cidadãos. À completude da garantia constitucional, não pode ser oposto o critério subjetivo definido em lei.

Para fïns da aplicação escorreita da LPAF, mais do que a classificação das diferentes instâncias da Administração Pública em função dos sujeitos que a integram (levando em conta os tenômenos da concentração e desconcentração). é de se ter em mira que suas prescriçôes aplicam-se tanto casso não haja personalidade jurídica própria (no casos dos órgãos), quanto caso haja personalidade própria (no caso das entidades), bem como, nos casos de haver poder de decisão (exercido por antoridade), ou quaisquer outros casos. Basta que se verifique exercício de função administrativa.

Não se pode pretender que a incidencia da Lei de Processo esteja sujeita a considerações bizantinas a respeito de elementos de classificação da atividade ad-

30 Redação dada pelo art. $1^{\circ}$ I da l.ei nº $7.596 / 87$.

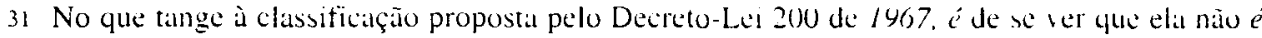
exclusiva do ambito Federal, as categorias mencionadas aplicam-se ao âmbito. Estadual. Municipal e Distrital (cf. ZANELLA DI PIETRO: Maria Sylvia in Dircile adminisratro, $10^{*}$ cel Său Paulu: Atlas, 1999. p. 56). 
ministrativa em função de critérios meramente subjetivos. As classifïcações, conforme lição já célebre, são sindicadas pelo critério de sua utilidade. não sendo idôneo pôr em xeque a essência do que se pretende ordenar em função do critério de ordenação eleito. Ou seja. não é lícito com base na classificação buscar explicar o fenômeno classificado, por evidente tautologia do raciocínio.

Adverte Celso Antônio BANDEIRA DE MELLO que não se reduz o fénômeno do exercício da função administrativa à enunciação legal dos sujeitos que integram a Administração (como poderia se supor de uma leitura precipitada do art. $1^{\circ}$ da Lei 9.784/99, ou do Decreto-Lei 200 de 1967) ${ }^{i 2}$.

"percebe-se que o critério retor ala classificaģä foi o orgânico. também chamado subjetive. ( ... ) O modelo destarte concebido, é be'm de ver. revela-se inapto para descortinar todas as modalidades pelas anais se desempenham atividades administrativas páblicas. Com efeito, a expressão Administração indireta', que doutrinariamente deveria coincidir com Administração descentralizada', dela se afasta parcialmente. Por isto ficaram de fora da categorização como Administração indireta os casos em que a atividade administrativa é prestada por particulares, "concessionários de serviços públicos'. ou por delegados de função ou oficio páblico."

Logo, ao se interpretar o $\$ 2^{\circ}$ é de se ter em mira que é perfeitamente possivel que se aplique à Lei para além do que se define (em especial, levando em conta o disposto no Decreto-Lei 200) por órgão, entidade e autoridade, basta que haja exercício de função administrativa.

Apenas o exercicio da função administrativa está apto a determinar a incidência da LPAF juízo que não pode ser suplantado por nenhuma consideraçäo de ordem subjetiva.

Tanto é assim, que mesmo além do aparato da Administração, quer direta, quer indireta, aplicam-se as disposições da Lei, como bem se lê no $\$ 1^{\circ}$ que fixa a incidência dos seus dispositivos no âmbito do Legislativo e Judiciário quando a função que se está a desenvolver é administrativa. A prescrição do parágrafo anterior é clara ao sufragar as alegaçōes vestibulares.

Cabe, enfim. analisar brevemente os conceitos dos incisos do $\$ 2^{\circ}$ e o seu sentido em relação ao processo administrativo como entidade autônoma, atentos à advertência feita ao longo deste tópico de que estes critérios são auxiliares, contudo não têm aptidão de definir por si, quando a relação deve se dar sob o influxo do processo e das regras a ele inerentes.

32 BANDEIRA DE MELlo. Celso Antônio. Curso de direito "dministrativo. 14 "ed.. São Paulo: Malheiros, 2002, p. 137. 
Órgãos (inciso I). como assinala a unanimidade da doutrinat. sio apêndicer de pessoas jurídicas que integram a Administração Públical ${ }^{3.3}$ que não pussuem personalidade jurídica própria. Assim. é característica essencial do órgão, não possuir personalidade jurídica própria. O que identifica o órgão é o singelo exercício de competências que the são outorgadals pela pessoa jurídica a qual ele está jungido, desde. claro, que esta outorga afigure-se legítima. Sobre o tema. assinala Celso Antônio Bandeira de Mello:

"Os órgãos não passam de simples partições internas da pessona cuja intimidade integram, isto é, näo te'm a personalidade jurídical ... ) Em sintese', juridicamente falando, não há. èn sentido próprio, relaçäe entre cirgüos. e muito menos entre eles e outras pessoas, visto que. naio tendo personalidade. os úrgãos não podem ser sujeitos de direitos e obrigaçōes." 3.t

Identifica-se órgão em função do exercício de competência (mesmo que seja de julgamento), sem que no entanto este exercício possa vir a instaurar uma relação autônoma entre o órgão e quem quer quue seja. Tall idvertência assume extremo relevo no que toca ao estudo do âmbito do processo administrativo, para que não se incida no vício de se supor que a relação processual vincula o órgão propriamente dito. Mesmo que o órgão exerça uma competência decisória. por exemplo nos termos do art. 11 da LPAF, ${ }^{35}$ é de se ver que tal fenômeno decorre de uma partiçío interna de competências e não autoriza a suposição de haver relação entre o órgão e quem quer que seja. Neste caso, o órgão será incumbido da tramitação do processo, contudo o provimento final a ser exarado não sujeita o órgão a nada e sim vincula a entidade efetivamente dotada de personalidade.

A relação vincula o ente efetivamente dotado de personalidade ao qual o órgão está sujeito. Os órgãos têm relevo para a lei na medida em que, nada obstante não seja parte da relação processual, eles são focos de competência. Além da possibilidade de haver órgãos com competências decisórias eles podem ser chamados a

33 Por vezes, identificam-sc os órgãos exclusivamente como produto da desconcentração efetuada dentro do seio da Administraçũo Pública direta, sendo esce fenôneno estranho a Administração indireta. É, neste sentido. o magistério abalizado de Marria Sylvia Zanella de Pietro: "compõem a

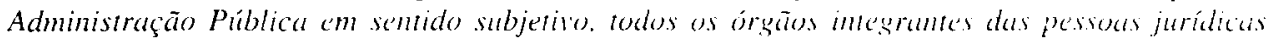
políticas (União. Estados. Manicípios e Distrito Federal) as quats a lei contere o exercicio de funçōes administrativas. Säo os órgãos da Administraçäo Diruta do Estade" in Direitu administrativo, 10" ed., São Paulo: Atlas. 1999, p. 56). Com a escusa do entendimento transcrito, crê-se nada obstar que o fenômeno se dê no bojo da Administração indireta, nada vedando que seus integrantes deleguem funçoes dentro da estrutura com vistas a melhor attender as suils finalidades. Neste sentido pertine a altusão de órg̣ăos integrantes da Administração indireta. Parece ser inclusive este o espírito da Lei $9.78+/ 99$ que identifica orgäos tanto no bojo da Administraçio direta, quanto indireta.

34 Op. cit.. p. 122 e 123.

35 "Art. 11. A competência é irrenunciárel e se excrce pelos órgăos administrativos al que foi

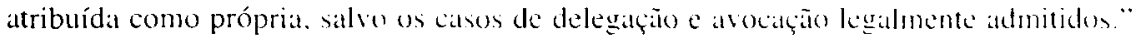


participar da prática de certos atos processuais. sem contudo assumir a condição de parte (pois não estão vinculados ao provimento final). Neste sentido, temos o exemplo, v.g., de pareceres que devem ser exarados para a instrução do processo. dentre outros exemplos que podem ser colhidos da LPAF. ${ }^{36}$

Entidades (inciso II), para fïns da LPAF, são todos os entes que exercem função administrativa - "unidade de atuaçāo" (em regime de prerrogativas e sujeições), dotados de personalidade jurídica própria. Como avulta com clareza da análise dos dispositivos em análise, distinguem-se os Órgãos das entidades em face da presença ou não de personalidade jurídica. Acresça-se a isto. que é irrelevante para fins de determinar a incidência ou não de regras de processo administrativo que a personalidade seja de direito público, pois, nos casos em que se estiver diante de pessoa de direito privado que esteja fazendo as vezes do Estado devem incidir tais normas no que houver exercício de função administrativa. Veja-se com isto, que estão a ser rompidos os cânones do DL $n^{\circ}$ 200/67 por não se adotar o critério de administração direta ou indireta (como se faz tradicionalmente) e sim vincular, à relação processual, as entidades dotadas de personalidade própria.

Nos casos onde haja personalidade jurídica própria a relação processual se estabelece diretamente com a entidade, que age em nome próprio e responde, portanto, seus atos.

Por fim, autoridade (inciso III) é conceito que vem vincular os agentes que desempenham em concreto a função pública, haja vista as pessoas morais não agirem concretamente, senão por meio de pessoas naturais que dão animo às previsões abstratas que estruturam as personalidades advindats da lakão legal." Novamente, o critério é de auxílio na medida em que mesmo sem as autoridades integrarem diretamente o processo administrativo devem dele participar, por vezes. Assim não estão indenes da aplicação da Lei, naquilo que lhes for pertinente, as autoridades, quando chamadas a participar da relação processual administrativa.

O que importa concluir da análise da classificação imposta pela LPAF, é que mais importante do que tentar determinar o seu âmbito de incidência com fulcro na classificação proposta, é notar que o critério que governa sua aplicação (em especial, no que toca a processo propriamente dito) é o desempenho de função público sob o

36 A título meramente exemplificativo é possivel consultar os seguintes artigos: "Art. 35. Quando necessária à instrução do processo, a audiência de outros órgãos ou entidades administrativas poderá ser realizada em reunião conjunta, com a participação de titulares ou representantes dos órgãos competentes, lavrando-se a respectiva alta, a ser juntiada alos autos": "Art. 42. Quando deva ser obrigatoriamente owido um árgão consultivo, o parecer deverá ser emitido no prazo máximo de quinze dias, salvo norma especial ou comprovada necessidade de maior prazo", dentre outros que fixam a participação de órgãos no correr do processo.

37 Neste ponto é de se destaciar a crítica de CARVALHO FILHO, José dos Santos in Processo Administrativo Federal - comentários à Lei 9.784 de 29.1.1999. Rio de Janeiro: Lumen Juris, 2001.p. 47 e 48 e ss) que prefere a dicção "agentes páblicos" que seria gênero. Parece-nos, contudo, que a diç̧ão "autoridade", por ter assento constitucional, (art., 5," LXIX) não padece de nenhuma imprecisão digna de crítica. 
influxo do regime jurídico administrativo (prerrogativas e sugestões). Os conceitos postos em elenco são instrumentais e não bastam por si sós para definir a incidência ou não das normas de processo contidas na Lei: é a dignidade constitucional do instituto que não permite o reducionismo de se tomar a classificação como essência.

\section{5 - Conclusões pontuais}

A análise do art. $1^{\circ}$ da LPAF, como tentou demonstrar-se, rende ensejo a vastas consideraçōes acerca do tema processo administlativo. Algumas delas buscou-se tratar com minudência, outras apenas fïcaram indicadas ou sugeridas em nome da delimitação proposta. O que é de se ter por definitivo é que nada do conteúdo apresentado está indene de crítica. o objetivo único era lançar algumas inflexões críticas acerca do tema processo administrativo gue está a merecer maiores atenções.

Contudo, a bem da operacionalidade e da ampla possibilidade de sindicância. faz-se necessário apresentar um arremate para a discussão proposta. Seguindo a linha metodológica adotada, que reclama análise crítica das propostas apresentadas, meIhor será fazer una recolha dos pontos defendidos do que arvorar-se de proposições que incidam no vezo de pretender a perenidade.

Em rasa síntese, reduz-se o texto aos seguintes pontos de discussão:

1. Contraditório e ampla defesa são garantias fundamentais que sujeitam todo o exercicio do poder estatal (fimçóes executisa. legislativa e judiciária) à sua irrestrita observância:

2. Tal garantia é una em todos os quadrantes da Federação, devendo ser ofertado integralmente o devido processo legal toda vez que a Constituição o impuser como necessário à prática de atos estatais:

3. Processo e procedimento no que toca ao exercicio de funçio administrativa são conceitos distintos face à Constituição sendo modos absolutamente diferentes de desempenhar/concretizar as competências conferidas à Administração:

4. Processo, por injunção constinucional, vincula-se à noção de conflituosidade que se, e quando, verificada predica o contraditório e a ampla defesa, agregando necessariamente a participaçäo do interessado para a prática do ato que institucionalmente compöe o conflito;

5. Procedimento, ao seu turno, indica a maneira como irá se concretizar a possibilidade de agir outorgada abstratamente por uma competencia previamente delimitada, circunscrevendo o agir da Administrasiós dentro de uma pauta racional e, pois, controlivel;

6. Nos termos da Constituiçäo Federal. "processo" e "procedimento" são realidades inconfundíveis, pensar de modo diverso seria amular a inteligências da norma que atribui exclusivamente à Uniāo legislar sobre processo.

7. As normas de processo vertidas na LPAF ienquanto normas que se vinculam a compor conflitos tratado de contraditório e ampla defesa) devem ser aplicadas para além da esfera federal, valendo para o Distrito Federal, Estados e Municípios também; 
8. Já as normas que referem-se a procedimento, que não cuidem do devido processo legal, têm sua aplicabilidade restrita ao âmbito federal apenas;

9. É o exercício por parte da Uniāo da sua competência privativa para legislar sobre processo que vincula a aplicação direta da Lei $n^{\circ} 9.784 / 99$ em todos os niveis da Administração Pública;

10. O critério que governa a aplicação da le é é malerial e vincula-se ao exercicio de função administrativa voltada a surtir efeitos no patrimônio jurídico dos cidadãos $e$ independe da adoção de critérios subjetivos ou orgânicos. 


\section{O Problema de uma Sociologia do Direito}

Evaristo de Moraes Filho

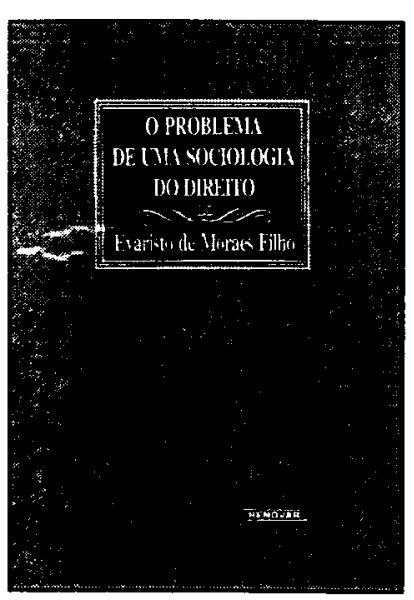

Na presente obra, o autor nāo teve em mira propósitos críticos ao expor doutrinas alheias, a não ser na parte final, quando teve de concluir e delimitar a posiçāo da sociologia do direito junto às demais disciplinas teóricas e gerais que cuidam também do fenômeno jurídico.

Ref. 0136

Encadernado 262 págs.

Form. 16x23 1997

\section{Ordem e Hermenêutica}

Nelson Saldanha

Esta obra toma a ordem como algo fundamental na experiência dos homens, e seu conceito como uma constante no pensamento de todas as épocas. A análise deste tema constitui uma ampla problemática, incluindo o estudo das formas do poder e as diferentes posições que se assumem diante do fenômeno da ordem. Em face da ordem política e do ordenamento jurídico, tais posiçōes se organizam como uma hermenêutica, e esse pensamento, no caso do Direito, se desenvolve como uma interpretação.

Ref. 0047

Form. 14x21
Brochura 1992

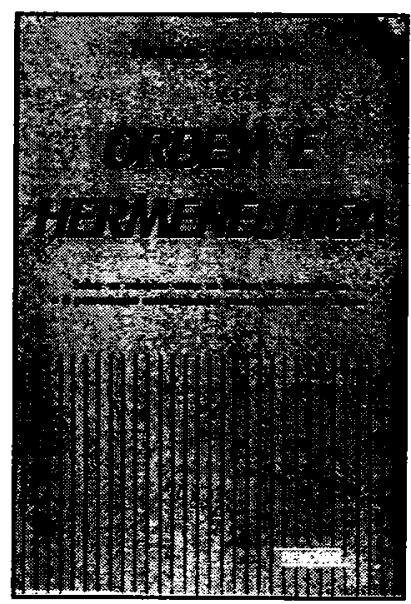

